\title{
In vitro antimicrobial properties of plant essential oils thymus vulgaris, cymbopogon citratus and laurus nobilis against five important foodborne pathogens
}

\author{
Propriedades antibacterianas in vitro de óleos essenciais de thymus vulgaris, cymbopogon citratus e \\ laurus nobilis contra cinco importantes bactérias patogênicas veiculadas por alimentos
}

\author{
Alessandra Farias MILLEZI ${ }^{1 *}$, Danila Soares CAIXETA ${ }^{1}$, Diogo Francisco ROSSONI ${ }^{2}$, \\ Maria das Graças CARDOSO ${ }^{3}$, Roberta Hilsdorf PICCOLI ${ }^{4}$
}

\begin{abstract}
Several essential oils of condiment and medicinal plants possess proven antimicrobial activity and are of important interest for the food industry. Therefore, the Minimum Inhibitory Concentrations (MIC) of those oils should be determined for various bacteria. MIC varies according to the oil used, the major compounds, and the physiology of the bacterium under study. In the present study, the essential oils of the plants Thymus vulgaris (time), Cymbopogon citratus (lemongrass) and Laurus nobilis (bay) were chemically quantified, and the MIC was determined on the bacteria Staphylococcus aureus ATCC 25923, Escherichia coli ATCC 25922, Listeria monocytogenes ATCC 19117, Salmonella enterica Enteritidis S64, and Pseudomonas aeruginosa ATCC 27853. The essential oil of C. citratus demonstrated bacterial activity at all concentrations tested and against all of the bacteria tested. The majority of essential oil compounds were geranial and neral. The major constituent of T. vulgaris was 1.8-cineol and of L. nobilis was linalool, which presented lower antibacterial activity, followed by 1.8-cineol. The Gram-negative bacteria demonstrated higher resistance to the use of the essential oils tested in this study. E. coli was the least sensitive and was inhibited only by the oils of C. citratus and L. nobilis.
\end{abstract}

Keywords: natural antimicrobials; essential oils; foodborne pathogens.

\section{Resumo}

Diversos óleos essenciais de plantas condimentares e medicinais possuem atividade antimicrobiana comprovada, sendo de grande interesse para a indústria de alimentos. Dessa forma, as Concentrações Mínimas Inibitórias (CMI) desses óleos para diversas bactérias devem ser determinadas. As CMI variam de acordo com o óleo utilizado, dos compostos majoritários e da fisiologia da bactéria em estudo. Na presente pesquisa, os óleos essenciais das plantas Thymus vulgaris (tomilho), Cymbopogon citratus (capim-limão) e Laurus nobilis (louro) foram quantificados quimicamente e determinou-se a CMI sobre as bactérias Staphylococcus aureus ATCC 25923, Escherichia. coli ATCC 25922, Listeria monocytogenes ATCC 19117, Salmonella entérica Enteritidis S64 e Pseudomonas aeruginosa ATCC 27853. O óleo essencial de C. citratus demonstrou atividade bacteriana em todas as concentrações testadas e sobre todas as bactérias, sendo seus constituintes majoritários o geranial e neral. O constituinte majoritário de T. vulgaris foi 1,8 cineol e do óleo de L. nobilis, que apresentou menor atividade antibacteriana, foi o linalool, seguido pelo 1,8 cineol. As bactérias Gram-negativas demostraram maior resistência perante o uso dos óleos essenciais testados neste estudo, E. coli foi a menos sensível, sendo inibida apenas pelos óleos de C. citratus e L. nobilis.

Palavras-chave: antimicrobianos naturais; microrganismos; patógeno alimentar.

\section{Introduction}

The essentials oils are products of the secondary plants' metabolism and several of them are used as seasonings and medicines. They can be defined as complex mixtures of volatile, lipophilic, odoriferous, and liquid substances (SIMÕES; SPITZER, 2004). The essential oils play an important role in plant protection such as antibacterial, antiviral, antifungal, insecticidal properties and also against herbivore attack. Currently, 3.000 essentials oils are known, 300 of which are commercially important in the pharmaceutical, agronomic, food, sanitation, cosmetics, and perfume industries (BAKKALI et al., 2008).
The antimicrobial properties of condiment and medicinal plant essential oils have been stirring interest from the perspective of their making up an alternative to the use of chemical additives in foods. In recent years, it has been related that some essentials oils are capable of inhibiting bacteria of food origin and prolonging the shelf life of processed foods (KIM et al., 1995; SMITH-PALMER; STEWART; FYFE, 1998). Due to their hydrophobic characteristic, these compounds act over the lipids of the cell membrane modifying its structure and turning it more permeable, allowing the passage of ions and or other substances.

\footnotetext{
Received 1/9/2010

Accepted 24/10/2011 (005024)

Agricultural Microbiology Sector, Biological Sciences Department, Federal University of Lavras - UFLA, Av. Silvio Minecucci, 1695/304, CEP 37200-000, Lavras, MG, Brazil, e-mail:amillezi@yahoo.com.br

2 Exact Sciences Department, Federal University of Lavras - UFLA, Lavras, MG, Brazil

${ }^{3}$ Chemistry Department, Federal University of Lavras - UFLA, Lavras, MG, Brazil

${ }^{4}$ Food Science Department, Federal University of Lavras - UFLA, Lavras, MG, Brazil

${ }^{*}$ Corresponding author
}

DOI: http://dx.doi.org/10.1590/S0101-20612012005000021 
According to Sikkema, Bont and Poolman (1994), essential oils accumulate in the cytoplasmic membrane and cause damage such as loss of function of selective barrier. In recent years, several reports have been published on the composition and biological properties of essential oils of several condiment plants, among them Thymus vulgaris, Cymbopogon citratus, and Laurus nobilis (FABIO et al., 2007; OLIVEIRA et al., 2009; SMITH-PALMER; STEWART; FYFE, 2001). A medicinal and aromatic plant, C. citratus originated from India. In Brazil, it is known as grass cider, smelling grass, and lemon balm. It grows well in regions with warm climates, and it has lemonlike flavor and aroma. According to history, it was introduced in Brazil during the colonial period and extended to all areas due to the easy adaptability to climate and different soil types (TESKE; TRENTINI, 1997; NEGRAES, 2003). Thymus vulgaris, a perennial labiate, is endemic in the Mediterranean area (DOMMÉE; ASSOUAD; VALDEYRON, 1978; GIGORD et al., 1999). The oblong oval dark green leaves with lengths between 6 and $12 \mathrm{~mm}$ and winding leaf edge are characteristic traits of T. vulgaris. It is a medicinal and spice plant. The essential oil of thyme is a flavor additive and an antimicrobial and antioxidative agent (NASCIMENTO et al., 2000; BAUER; LUF, 2002). Laurus nobilis is a native species to the Mediterranean region, which is cultivated in many countries with moderate and subtropical climate (DI LEO LIRA et al., 2009). Laurus nobilis is commonly known as bay, and true laurel, it is an every green tree that reaches up to $8 \mathrm{~m}$ in height. Dried bay leaves are mainly used as a spice and flavoring agent in culinary (AFIFI et al., 1997, DI LEO LIRA et al., 2009).

Some researches emphasize the existence of differences in the chemical composition among the extracted oils of different species or varieties. These variations tend to influence the antimicrobial activity of the oils and usually depend on factors such as genetically determined properties, plant age, seasonal variation, water availability, environmental temperature at which the plant is found, nutrients available in the soil, altitude, and UV radiation (MARTINS et al., 2003; GOBBO-NETO; LOPEZ, 2007).

The food contaminating bacterial microbiota is widely diversified. Among the most important pathogenic bacteria are Staphylococcus aureus, Listeria monocytogenes (Gram-positive bacteria), Escherichia coli, Salmonella enterica Enteritidis, and Pseudomonas aeruginosa (Gram-negative bacteria). Staphylococcus aureus is responsible for causing toxinosis outbreaks, and the main habitat in humans and animals is the naso-pharyngeal mucous membrane, where it forms part of the normal microbiota (FUEYO; MENDONZA; MARTÍN, 2005). Escherichia coli is the causal agent of gastroenteritis, the contamination is caused mainly by contact with fecal matter or contact with contaminated surfaces (NASCIMENTO; STAMFORD, 2000). Listeria monocytogenes is considered one of the five most important foodborne pathogens.

It causes listeriosis, which is a serious disease of atypical food origin with long incubation period (LOGUERCIO et al., 2001). The serovar S. enterica Enteritidis has been identified as the cause of most of the salmonellosis diseases investigated in the Brazilian States of Rio Grande do Sul, Santa Catarina, Paraná, and São Paulo in the last few years (ALCOCER et al.,
2006; GEIMBA et al., 2004, TAVECHIO et al., 2002). Pseudomonas aeruginosa is a virulent bacterium with the capacity to adhere to inanimate and biological surfaces causing various infections (CAPPELLO; GUGLIELMINO, 2006).

As a result, the objective of the present study was to evaluate the inhibitory in vitro effect of the essential oils of C. citratus, T. vulgaris, and L. nobilis on the growth of the microorganisms Staphylococcus aureus ATCC 25923, Escherichia coli ATCC 25922, Listeria monocytogenes ATCC 19117, Salmonella enterica Enteritidis S64, and Pseudomonas aeruginosa ATCC 27853.

\section{Materials and methods}

\subsection{Location where the study was carried out}

This research was developed at the Federal University of Lavras - Minas Gerais (UFLA-MG), where the extraction of the essential oils and determination of their chemical composition were conducted in the Organic Chemistry and Chromatography Laboratories, respectively, while the microbiological analyses were carried out in the Food Microbiology Laboratory, in the Food Science Department.

\subsection{Microorganism used and standardization of the inoculum}

The bacteria used in this experiment were Staphylococcus aureus ATCC 25923, Escherichia coli ATCC 25922, Listeria monocytogenes ATCC 19117, Salmonella enterica Enteritidis S64, and Pseudomonas aeruginosa ATCC 27853. Throughout the experiment, the strains were stored under refrigeration in freezing culture medium $(15 \mathrm{~mL}$ glycerol, $0.5 \mathrm{~g}$ bacteriological peptone, 0.3 of yeast extract and $0.5 \mathrm{~g} \mathrm{NaCl}$, per $100 \mathrm{~mL}$ of distilled water, with the final $\mathrm{pH}$ adjusted to 7.2-7.4). The standardization of the number of cells was determined by calibration curve. Bacterial populations in the inoculum were determined using a spectrophotometer (CARY Varian Inc.), optical density (periodic absorbance readings) at $620 \mathrm{~nm}$, in Trypticase Soy Broth culture media (TSB, Himedia, Índia). Throughout the growth curve, cell counts were determined as $\log$ CFU.mL $L^{-1}$ by serial dilution in peptone water $0.1 \%$ $(\mathrm{w} / \mathrm{v})$ and subsequent enumeration on Trypticase Soy Agar (TSA, Himedia, Índia) by a spread plate methodology. For strain reactivation and use, an aliquot of the freezing culture medium was transferred to test tubes containing TSB with two subcultures at $37^{\circ} \mathrm{C}$ for 24 hours. The culture was striated in TSA added to Petri dishes and incubated at $37^{\circ} \mathrm{C}$ for 24 hours. Of the colonies formed on the TSA surface, some were removed and transferred to an Erlenmeyer flask containing $50 \mathrm{~mL}$ of TSB, which was incubated at $37^{\circ} \mathrm{C}$ until reaching the number of cells necessary for the experiment, approximately $10^{8}$ CFU.mL ${ }^{-1}$.

\subsection{Plant material}

The leaves of C. citratus used were obtained from the Medicinal Plant Nursery of UFLA. The samples were collected at 8:00 A.M., on sunny, non-rainy days, in September 2009, under a temperature of approximately $20^{\circ} \mathrm{C}$ (MARTINS et al., 1994). 
The leaves of T. vulgaris were acquired from the local market of the city of Lavras, MG, and the leaves of L. nobilis were collected at 6:00 P.M., on sunny, non-rainy days, in October 2009 in the region of Patos de Minas (Minas Gerais-Brazil).

\subsection{Extraction of essential oils}

The essential oil extraction process was conducted using the hydrodistillation method using a modified Clevenger apparatus connected to a $4 \mathrm{~L}$ round-bottom, ground mouth flask (CASTRO et al., 2006). The extraction process was conducted for a period of two hours while the solution was kept boiling. Later, the hydrolate (water and oil) was collected and centrifuged, at $321.8 \times$ G, for 5 minutes, in a Fanem-Baby I Mod 206 centrifuge, for the separation of the organic phase from the aqueous phase. The essential oil was then isolated with the aid of a Pasteur pipette, placed in a glass bottle and stored under refrigeration.

\subsection{Quantification of constituents of essential oils}

For the qualitative evaluation of the essential oils, they were submitted to gas chromatography coupled with mass spectrometry (GC/MS) using the Shimadzu model GCMS QP2010 Plus apparatus. The operational conditions were: fused silica capillary column $(30 \mathrm{~m} \times 0.25 \mathrm{~mm})$ with DB5 bonded phase, helium carrier gas, flow rate $1 \mathrm{~mL} / \mathrm{minute}$, injector temperature $220^{\circ} \mathrm{C}$, detector temperature of $240{ }^{\circ} \mathrm{C}$, and oven temperature program of $40^{\circ} \mathrm{C}$ increasing $3{ }^{\circ} \mathrm{C} /$ minutes.

The compounds were identified by comparisons with spectra existing in the literature (Wiley 8 and FFNSC 1.2) and using the Kovat's index (ADAMS, 2007).

\subsection{Determination of the minimum inhibitory concentration of the essential oils}

The minimum inhibitory concentration (MIC) of essential oils was determined using the technique of disk diffusion in agar proposed by National Committee for Clinical Laboratory Standards (M7-A6) (2003) with modifications. The essential oils were diluted in dimethyl sulfoxide (DMSO) at different concentrations $(0.5,1.5,2.5,5.0,10.0,15.0,25.0$, and $50.0 \%)$ and with DMSO control. The bacterial inoculum (in TSB) were added to vials containing TSA, the cell concentration was standardized to approximately $10^{8} \mathrm{CFU} \cdot \mathrm{mL}^{-1}$, and the inocolum was poured directly into sterile Petri dishes $(150 \mathrm{~mm})$. After solidification, a volume of $5 \mu \mathrm{L}$ of each OE was dispensed on filter paper discs $6 \mathrm{~mm}$ in diameter, which were placed on TSA inoculated. The plates were incubated in B.O.D. at $37^{\circ} \mathrm{C}$ for 24 hours (OGUNWANDE et al., 2005). The diameters of the inhibition halos formed were measured using a caliper rule. The analyses were conducted in triplicate.

\subsection{Statistical analysis}

The experimental design was completely randomized in a factorial outline with three repetitions. The statistical analysis of the data was performed using the statistical program SISVAR (FERREIRA, 2008). For comparison of the averages, the Tukey test at the $5 \%$ of probability level was used.

\section{Results and discussion}

\subsection{Chemical composition of essential oils}

The major constituents found in the essential oil of T. vulgaris were identified as in decreasing order: 1.8-cineol, 4 terpineol, and trans-caryophyllene. The major compound 1.8-cineol, a monoterpenoid, possesses antimicrobial activity (GILLES et al., 2010) and has already been related by several researchers as a possible major constituent of the essential oil of thyme, depending on the developmental stage of the plant (JORDÁN, 2006).

A study carried out by Sacchetti et al. (2005), on the chemical constituents of the essential oil of $C$. citratus with analysis by GC/MS, found $0.43 \%$ eptem-methyl-5-2-one, $15.48 \%$ myrcene, $1.28 \%$ linalool, $32.3 \%$ neral, $3.35 \%$ geraniol, and $41.3 \%$ of geranial. Those results were similar to those found in the present study; geranial $(47.03 \%)$ was the compound found in highest amount, followed by neral (35\%) and myrcene (8.88\%).

The evaluation of the essential oil of L. nobilis presented linalool as its major constituent, followed by 1.8-cineol, a-Terpinyl acetate and Terpinen-4-ol. Kovacevic, Simic and Ristic (2007) argue that besides the differences in the makeup of the essential oils from the same plant species, variations also occur depending on the part of the plant that is used for the extraction because the composition of the essential oil of the flowers and bay leaves present some differences in the amount of the constituents. Di Leo Lira et al. (2009) found 1.8-cineol as the major component of the essential oil of bay leaves obtained in different months of the year, followed by linalool, sabinene and $\alpha$-Terpinyl acetate. Jelnar et al. (2010) argue that in the analysis of volatile oil of fresh L. nobilis leaves, 1.8-cineol (eucalyptol) (40.91\%) was the major component. Some other detected monoterpenes were $\alpha$-pinene $(5.82 \%), \beta$-pinene (4.55\%), sabinene (6.92\%), limonene (2.10\%), linalool (1.29\%), and $\alpha$-terpinyl acetate $(5.86 \%)$.

\subsection{Antimicrobial activity}

The microbiological assays demonstrated that the essential oils presented considerable activity against the bacteria under study. The data described in Table 1 show that L. monocytogenes was more sensitive to $C$. citratus essential oil at all concentrations used in this experiment; the diameter of the inhibition halo was directly proportional to the concentration increase. However, that oil was significantly more effective against $L$. monocytogenes at the concentrations of 25 and 50\%, and for P. aeruginosa it started at 5\% (Table 2). Against S. aureus, at the lowest used concentration, $0.5 \%$, there was a significant difference in C. citratus oil compared to T. vulgaris and L. nobilis (Table 3). On the other hand, there was a significant difference for the bacteria S. enterica Enteritidis, starting from the concentration of $2.5 \%$. The differences between the antimicrobial activity of oil were significant (Table 4). It was verified that on L. monocytogenes, the diameter of the C. citratus inhibition halo was smaller at the concentrations 0.5 and $1.5 \%$ (Table 1 ), and it was more statically efficient at the concentrations above $15 \%$. In a study using 52 
Table 1. Inhibition zones diameters $(\mathrm{mm})$ by different concentrations of essential oils on Listeria monocytogenes without considering the disc diameter.

\begin{tabular}{cccc}
\hline $\begin{array}{c}\text { Concentration } \\
(\%)\end{array}$ & Thymus vulgaris & Cymbopogon citratus & Laurus nobilis \\
\hline Control & 0.00 & 0.00 & 0.00 \\
0.5 & $3.83^{\mathrm{b}}$ & $2.67^{\mathrm{ab}}$ & $0.00^{\mathrm{a}}$ \\
1.5 & $4.00^{\mathrm{b}}$ & $3.33^{\mathrm{b}}$ & $0.00^{\mathrm{a}}$ \\
2.5 & $3.83^{\mathrm{b}}$ & $4.00^{\mathrm{b}}$ & $0.00^{\mathrm{a}}$ \\
5.0 & $3.83^{\mathrm{ab}}$ & $4.67^{\mathrm{b}}$ & $1.00^{\mathrm{a}}$ \\
10.0 & $4.83^{\mathrm{b}}$ & $6.33^{\mathrm{b}}$ & $1.00^{\mathrm{a}}$ \\
15.0 & $6.00^{\mathrm{a}}$ & $7.33^{\mathrm{a}}$ & $4.33^{\mathrm{a}}$ \\
25.0 & $6.00^{\mathrm{a}}$ & $14.33^{\mathrm{b}}$ & $5.67^{\mathrm{a}}$ \\
50.0 & $6.33^{\mathrm{a}}$ & $14.33^{\mathrm{b}}$ & $5.67^{\mathrm{a}}$ \\
\hline
\end{tabular}

${ }_{\mathrm{a}, \mathrm{b}}$ Tukey Test at $95 \%$ significance for differences of the inhibition zone averages (measured in millimeters). Averages followed by same letter in line do not differ significantly.

Table 2. Inhibition zones diameters ( $\mathrm{mm}$ ) by different concentrations of essential oils on Pseudomonas aeruginosa without considering the disc diameter.

\begin{tabular}{cccc}
\hline $\begin{array}{c}\text { Concentration } \\
\text { (\%) }\end{array}$ & Thymus vulgaris & Cymbopogon citratus & Laurus nobilis \\
\hline Control & 0.00 & 0.00 & 0.00 \\
0.5 & $0.00^{\mathrm{a}}$ & $6.00^{\mathrm{b}}$ & $0.00^{\mathrm{a}}$ \\
1.5 & $0.00^{\mathrm{a}}$ & $6.83^{\mathrm{b}}$ & $0.00^{\mathrm{a}}$ \\
2.5 & $0.00^{\mathrm{a}}$ & $6.83^{\mathrm{b}}$ & $0.00^{\mathrm{a}}$ \\
5.0 & $6.50^{\mathrm{b}}$ & $21.67^{\mathrm{c}}$ & $0.00^{\mathrm{a}}$ \\
10.0 & $7.00^{\mathrm{b}}$ & $19.33^{\mathrm{c}}$ & $0.00^{\mathrm{a}}$ \\
15.0 & $7.17^{\mathrm{b}}$ & $19.00^{\mathrm{c}}$ & $4.00^{\mathrm{a}}$ \\
25.0 & $7.50^{\mathrm{a}}$ & $24.17^{\mathrm{b}}$ & $5.17^{\mathrm{a}}$ \\
50.0 & $8.83^{\mathrm{a}}$ & $29.50^{\mathrm{b}}$ & $4.83^{\mathrm{a}}$ \\
\hline a,b,c,Tukey Test at 95\% significance for differences of the inhibition zone averages (measured \\
in millimeters). Averages followed by same letter in line do not differ significantly.
\end{tabular}

Table 3. Inhibition zones diameters $(\mathrm{mm})$ by different concentrations of essential oils on Staphylococcus aureus without considering the disc diameter.

\begin{tabular}{cccc}
\hline $\begin{array}{c}\text { Concentration } \\
(\%)\end{array}$ & Thymus vulgaris & Cymbopogon citratus & Laurus nobilis \\
\hline Control & 0.00 & 0.00 & 0.00 \\
0.5 & $2.00^{\mathrm{b}}$ & $5.00^{\mathrm{c}}$ & $0.00^{\mathrm{a}}$ \\
1.5 & $2.00^{\mathrm{b}}$ & $5.33^{\mathrm{c}}$ & $0.00^{\mathrm{a}}$ \\
2.5 & $2.00^{\mathrm{b}}$ & $6.33^{\mathrm{c}}$ & $0.00^{\mathrm{a}}$ \\
5.0 & $2.00^{\mathrm{b}}$ & $5.83^{\mathrm{c}}$ & $0.00^{\mathrm{a}}$ \\
10.0 & $3.00^{\mathrm{b}}$ & $7.00^{\mathrm{c}}$ & $0.00^{\mathrm{a}}$ \\
15.0 & $3.33^{\mathrm{b}}$ & $6.83^{\mathrm{c}}$ & $0.00^{\mathrm{a}}$ \\
25.0 & $4.00^{\mathrm{b}}$ & $8.00^{\mathrm{c}}$ & $0.00^{\mathrm{a}}$ \\
50.0 & $5.00^{\mathrm{b}}$ & $11.67^{\mathrm{c}}$ & $3.00^{\mathrm{a}}$ \\
\hline
\end{tabular}

a,b,c Tukey Test at $95 \%$ significance for differences of the inhibition zone averages (measured in millimeters). Averages followed by same letter in line do not differ significantly.

different essential oils, only C. citratus, Pimenta racemosa and Origanum vulgare were efficient in the inhibition of $P$. aeruginosa (HAMMER; CARSON; RILEY, 1999).

With regard to the antimicrobial action of the oils on E. coli, the essential oil of bay was the most effective (Table 5). This could be attributed to the antimicrobial effect of the major compounds, linalool and 1.8-cineol, since in the literature, there
Table 4. Inhibition zones diameters $(\mathrm{mm})$ by different concentrations of essential oils on Salmonella enterica Enteritidis without considering the disc diameter.

\begin{tabular}{cccc}
\hline $\begin{array}{c}\text { Concentration } \\
(\%)\end{array}$ & Thymus vulgaris & Cymbopogon citratus & Laurus nobilis \\
\hline Control & 0.00 & 0.00 & 0.00 \\
0.5 & $0.00^{\mathrm{a}}$ & $5.17^{\mathrm{b}}$ & $0.00^{\mathrm{a}}$ \\
1.5 & $0.00^{\mathrm{a}}$ & $5.17^{\mathrm{b}}$ & $1.00^{\mathrm{a}}$ \\
2.5 & $0.00^{\mathrm{a}}$ & $6.33^{\mathrm{b}}$ & $1.00^{\mathrm{a}}$ \\
5.0 & $0.00^{\mathrm{a}}$ & $6.33^{\mathrm{c}}$ & $3.50^{\mathrm{b}}$ \\
10.0 & $1.33^{\mathrm{a}}$ & $7.00^{\mathrm{c}}$ & $4.67^{\mathrm{b}}$ \\
15.0 & $2.17^{\mathrm{a}}$ & $7.00^{\mathrm{b}}$ & $5.50^{\mathrm{b}}$ \\
25.0 & $2.83^{\mathrm{a}}$ & $8.00^{\mathrm{b}}$ & $8.50^{\mathrm{b}}$ \\
50.0 & $4.00^{\mathrm{a}}$ & $11.67^{\mathrm{c}}$ & $8.50^{\mathrm{b}}$ \\
\hline ab,c, Tukey Test at 95\% significance for differences of the inhibition zone averages (measured \\
in millimeters). Averages followed by same letter in line do not differ significantly.
\end{tabular}

Table 5. Inhibition zones diameters $(\mathrm{mm})$ by different concentrations of essential oils on Escherichia coli without considering the disc diameter.

Concentration Thymus vulgaris Cymbopogon citratus Laurus nobilis (\%)

\begin{tabular}{clll} 
Control & 0.00 & 0.00 & 0.00 \\
0.5 & $0.00^{\mathrm{a}}$ & $2.00^{\mathrm{a}}$ & $1.70^{\mathrm{a}}$ \\
1.5 & $0.00^{\mathrm{a}}$ & $3.80^{\mathrm{b}}$ & $3.80^{\mathrm{b}}$ \\
2.5 & $0.00^{\mathrm{a}}$ & $3.80^{\mathrm{b}}$ & $4.00^{\mathrm{b}}$ \\
5.0 & $0.00^{\mathrm{a}}$ & $3.80^{\mathrm{b}}$ & $5.80^{\mathrm{b}}$ \\
10.0 & $0.00^{\mathrm{a}}$ & $4.00^{\mathrm{b}}$ & $6.50^{\mathrm{b}}$ \\
15.0 & $0.00^{\mathrm{a}}$ & $4.30^{\mathrm{b}}$ & $8.20^{\mathrm{c}}$ \\
25.0 & $0.00^{\mathrm{a}}$ & $5.60^{\mathrm{b}}$ & $13.20^{\mathrm{c}}$ \\
50.0 & $6.50^{\mathrm{a}}$ & $5.60^{\mathrm{a}}$ & $14.00^{\mathrm{b}}$ \\
\hline
\end{tabular}

a,b,c Tukey Test at 95\% significance for differences of the inhibition zone averages (measured in millimeters). Averages followed by same letter in line do not differ significantly.

are already several reports that the essential oils containing alcohol terpenoids act strongly on the cytoplasmic membrane of the microorganisms (DI PASQUA et al., 2007). The essential oil of bay can be used as an antioxidant or natural preservative due to the presence of the terpene alcohols Terpinen-4-ol, and $\alpha$-Terpineol and phenols, which are also recognized as antimicrobial (BURT; REINDERS, 2004; BAKKALI et al., 2008; MITIC-CULAFIC et al., 2009). Thyme oil did not present antibacterial activity on E. coli.

According to Pereira et al. (2008), essential oils of C. citratus, O. vulgare, and Syzygium aromaticum showed antimicrobial effect on E. coli and $S$. aureus. With regard to the inhibitory effect of $C$. citratus essential oil on $S$. aureus, the concentrations between 0.1 and $20 \%$ did not present significant variation and were found constant for the other values (30,40, and $50 \%)$. However, the inhibitory effect of the same oil on E. coli did not present significant variation in the size of the halo at the concentrations of $0.1,0.5,1.0,5.0$, and $10 \%$, while at concentrations of $20,30,40$, and $50 \%$, a size variation was observed in relation to the results of the first group although among them, the values remained constant. Several authors, such as Pereira et al. (2008) and Duarte et al. (2007) consider that the major constituents of the essential oil of $C$. citratus and C. winterianus, monoterpenes geranial and neral, are responsible for the antibacterial action. However, the myrcene is an acyclic 
hydrocarbon, which polymerizes and resinifies when exposed to light, and it does not have antibacterial action (ONAWUNMI; YISAK; OGUNLANA, 1984).

Nedorostova et al. (2009) tested the essential oils of 27 plants species on L. monocytogenes ATCC 7644, S. aureus ATCC 25923, E. coli ATCC 25922, P. aeruginosa ATCC 27853, and S. enterica Enteritidis ATCC 13076. Of these, 13 were active, and only the essential oils of Allium sativum and Armoracia rusticana were capable of inhibiting all of the bacteria. Staphylococcus aureus was inhibited by all active oils, followed by E. coli (8), L. monocytogenes (7), S. enterica Enteritidis (6), and $P$. aeruginosa (2).

In the present study, the essential oil of $L$. nobilis demonstrated antibacterial activity against $L$. monocytogenes starting from the concentration of 5\% (Table 1) and against P. aeruginosa from 15\% (Table 2); against the bacteria S. aureus there was antimicrobial activity only at $50 \%$ concentration, the highest used (Table 3). However, for S. enterica Enteritidis the minimum inhibitory concentration was $2.5 \%$ (Table 4 ).

The minimum inhibitory concentration of the essential oil of T. vulgaris against $P$. aeruginosa (Table 2 ) and $S$. enteritidis was 5 and $10 \%$, respectively (Table 4 ). There was no significant difference among the other concentrations. On the other hand, the minimum inhibitory concentration was $0.5 \%$ for L. monocytogenes (Table 1) and S. aureus (Table 3). In a comparative analyses, it can be observed that the largest inhibition halo was obtained at the concentration of $50 \%$ for all bacteria tested, and the largest halo $(8.83 \mathrm{~mm})$ was observed for $P$. aeruginosa. Duarte et al. (2007) tested essential oils of several plants commonly used as medicines in Brazil against E. coli, and found that the essential oil of T. vulgaris inhibited, efficiently, 5 of the 13 serotypes of E. coli. Rota et al. (2008) found efficient antimicrobial activity of the essential oil of thyme against the bacteria E. coli, L. monocytogenes, S. enterica Enteritidis, and $S$. aureus, and timol was the major compound of thyme.

Some studies demonstrated that essential oils of oregano, thyme, and rosemary are among the more active antimicrobials (DIMITRIJEVIĆ et al., 2007). However, it can be observed in the present study that the largest inhibition halos were found for Cymbopogon citratus. According to Moreira et al. (2005), lipophilic compounds of the oils bond the phospholipid bilayer of the cell membrane increasing its permeability and spreading out the intracellular contents or damaging the enzymatic system of the cell. Souza et al. (2010) mention that even small changes occurring in the cytoplasmic membrane structure can affect the metabolism, including the macromolecule synthesis.

Staphylococcus aureus and L. monocytogenes are Gram positive bacteria, which can facilitate the action of the oils; in other words, there is high incorporation of the additive into the cell wall (HARPAZ et al., 2003). In a study using the same test conducted in vitro, Dorman and Deans (2000) used essential oils of clove, oregano, geranium, and pepper to evaluate their activity on 25 species of Gram-positive and Gran-negative bacteria. Those authors observed that Gram-positive bacteria were more susceptible to the essential oils studied than the Gram-negative bacteria.

\section{Conclusion}

The major compound of the essential oil of T. vulgaris was 1.8-cineol; of C. citratus it was geranial, and of $L$. nobilis it was linalool. The essential oils used in this study showed effective antimicrobial activity. The $C$. citratus essential oil was the most effective against the bacteria tested, except for $E$. coli, in which the L. nobilis oil presented a larger inhibition halo. T. vulgaris was more effective against Gram-positive bacteria, and the Gram-negative bacteria were more resistant.

\section{Acknowledgements}

The authors acknowledge the fellowship provided by the Coordination of Improvement of Higher Education Personnel (CAPES) to the first author and the Research Support Foundation of the State of Minas Gerais (FAPEMIG) for the financial support.

\section{References}

ADAMS, R. P. Identification of essential oils componets by gás chromatography/quadrupole mass spectroscopy. 4. ed. Carol Stream: Allured Publishing, 2007. 804 p.

AFIFI, F. U. et al. Evalution of the gastroprotective effect of Laurus nobilis seeds on ethanol-induced gastric ulcer in rats. Journal Ethnopharmacology, v. 58, p. 9-14, 2007. http://dx.doi.org/10.1016/ S0378-8741(97)00070-6

ALCOCER, I. et al. Discrimination of Salmonella serovars isolated from chicken meat by REP and ERIC-PCR and phagotyping of Enteriditis sorovar. Ciência e Tecnologia de Alimentos, v. 26, p. 1-16, 2006.

BAKKALI, F. et al. Biological effects of essential oils: a review. Food and Chemical Toxicology, v. 46, p. 446-475, 2008. PMid:17996351. http://dx.doi.org/10.1016/j.fct.2007.09.106

BAUER, F.; LUF, W. Antioxidative effects of herbs in meat products II - slow down in fat changes. Institute for Applied Botany, University of Veterinary Medicine, Vienna. Funktionelle Pflanzenstoffe in der Veterinarmedizin, Vienna, 2002.

BURT, S. A.; REINDERS, R. D. Antibacterial activity of selected plant essential oils against Escherichia coli O157:H7. Letters in Applied Microbiology, v. 36, p. 162-167, 2004. PMid:12581376. http:// dx.doi.org/10.1046/j.1472-765X.2003.01285.x

CAPPELLO, S.; GUGLIELMINO, S. P. P. Effects of grwth temperature on polystyrene adhesion of Pseudomonas aeruginsa ATCC 27853. Brazilian Journal of Microbiology, v. 37, p. 205-207, 2006. http:// dx.doi.org/10.1590/S1517-83822006000300001

CASTRO, D. P. et al. Não preferência de Spodoptera frugiperda (Lpdóptera: Noctuidae) por óleos essenciais de Achillea millefolium L. e Thymus vulgaris. Revista Brasileira de Plantas Medicinais, v. 8, p. 27-32, 2006.

DI LEO LIRA, P. et al. Essential oil and by-products of distillation of bay leaves (Laurus nobilis L.) from Argentina. Industrial Crops and Products, v. 30, p. 259-264, 2009. http://dx.doi.org/10.1016/j. indcrop.2009.04.005

DI PASQUA, R. et al. Membrane toxicity of antimicrobial coumpounds from essential oils. Journal of Agricultural and Food Chemystry, v. 55, p. 4863-4870, 2007. PMid:17497876. http://dx.doi. org/10.1021/jf0636465

DIMITRIJEVIĆ, S. I. et al. A study of the synergistic antilisterial effects of a sublethal dose of lactic acid and essential oils from Thymus vulgaris L., Rosmarinus officinalis L. and Origanum vulgare L. Food Chemistry, v. 104, p. 774-782,2007.http://dx.doi.org/10.1016/j.foodchem.2006.12.028

DOMMÉE, B.; ASSOUAD, M. W.; VALDEYRON, G. Natural selection and gynodioecy in T. vulgaris L. Botanical Journal 
of the Linnean Society v. 77, p. 17-28, 1978. http://dx.doi. org/10.1111/j.1095-8339.1978.tb01369.x

DORMAN, H. J.; DEANS, S. G. Antimicrobial agents from plants: antibacterial activity of plant volatile oils. Journal Applied Microbiology, v. 2, n. 88, p. 308-16. 2000. PMid:10736000. http:// dx.doi.org/10.1046/j.1365-2672.2000.00969.x

DUARTE, M. C. et al. Activity of essential oils from Brazil medicinal plants on Escherichia coli. Journal of Ethnopharmacology, v. 111, p. 197-201, 2007. PMid:17210236. http://dx.doi.org/10.1016/j. jep.2006.11.034

FABIO, A. et al. Screening of the antibacterial effects of a variety of essential oils on microorganisms responsible for respiratory infections. Phytotherapy Research, v. 21, p. 374-377, 2007. PMid:17326042. http://dx.doi.org/10.1002/ptr.1968

FERREIRA, D. F. Sisvar: um programa para análises e ensino de estatística. Revista Symposium, v. 6, p. 36-41, 2008.

FUEYO, J. M.; MENDONZA, M. C.; MARTÍN, M, C, Enterotoxins and toxic shock syndrome toxin in Staphylococcus aureus recovered from human nasal carriers and manually handled foods: epidemiological and genetic findings. Microbes and Infection, v. 7, p. 187-194, 2005. PMid:15715991. http://dx.doi.org/10.1016/j.micinf.2004.10.009

GEIMBA, M. P. et al. Serological characterization and prevalence of spvR genes in Salmonella isolated from foods involved in outbreaks in Brazil. Journal of Food Protection, v. 67, p. 1229-1233, 2004. PMid:15222555

GIGORD, L. et al. Evidence for effects of restorer genes on male and female reproductive functions of hermaphrodites in the gynodioecious species T. vulgaris L. Journal of Evolutionary Biology, v. 12, p. 596-604, 1999. http://dx.doi.org/10.1046/j.1420-9101.1999.00056.x

GILLES, M. et al. Chemical composition and antimicrobial properties of essential oils of three Australian Eucalyptus species. Food Chemistry, v. 119, p. 731-737, 2010. http://dx.doi.org/10.1016/j. foodchem.2009.07.021

GOBBO-NETO, L.; LOPES, N. P. Plantas medicinais: fatores de influência no conteúdo de metabolitos secundários. Química Nova, v. 30, p. 374-381, 2007. http://dx.doi.org/10.1590/S010040422007000200026

HAMMER, K. A.; CARSON, C. F.; RILEY, T. V. Antimicrobial activity of essential oils and other plant extratcts. Journal of Applied Microbiology, v. 86, p. 985-990, 1999. PMid:10438227. http://dx.doi. org/10.1046/j.1365-2672.1999.00780.x

HARPAZ, S. et al. Effects of herbal essential oils used to extend the shelf life of freshwater-reared Asian Sea Bass fish (Lates calcarifer). Journal of Food Protection, v. 66, p. 410-417, 2003. PMid:12636293

JELNAR, Z. et al. Volatile oil composition and antiproliferative activity of Laurus nobilis, Origanum syriacum, Origanum vulgare, and Salvia triloba against human breast adenocarcinoma cells. Nutrition Research, v. 1, n. 4, p. 217-278, 2010.

JORDÁN, M. J. et al. A. Seasonal variation of Thymus hyemalis Lange and Spanish Thymus vulgaris L. essential oils composition. Industrial Crops and Products, v. 24, p. 253-263, 2006. http://dx.doi. org/10.1016/j.indcrop.2006.06.011

KIM, J. M. et al. Antibacterial activity of carvacrol, citral, and geraniol against Salmonella typhimurium in culture medium and on fish cubes. Journal of Food Science, v. 60, p. 1364-1368, 1995. http://dx.doi. org/10.1111/j.1365-2621.1995.tb04592.x

KOVACEVIC, N, N.; SIMIC, M. D.; RISTIC, M. S. Essential oil of Laurus nobilis from montenegro. Chemistry of Natural Compounds, v. 43, p. 408-411, 2007. http://dx.doi.org/10.1007/s10600-007-0150-x

LOGUERCIO, A. P. et al. Listeria monocytogenes: um importante patógeno de origem alimentar. Revista Higiene Alimentar, v. 15, p. 39-48, 2001.

MARTINS, E. R. et al. Plantas medicinais. Viçosa: UFV, 2003, p. 20

MARTINS, R. E. et al. Plantas medicinais. Viçosa: UFV, 1994. 220 p.

MITIC-CULAFIC, D. et al. Protective effect of linalool, myrcene and eucalyptol against tbutyl hydroperoxide induced genotoxicity in bacteria and cultured human cells. Food Chemistry Toxicology, v. 47, p. 260-266, 2009. PMid:19049815. http://dx.doi.org/10.1016/j. fct.2008.11.015

MOREIRA, M. R. et al. Inhibitory parameters of essential oils to reduce a foodborne pathogen. LWT-Food Science and Technology, v. 38, p. 565-570, 2005. http://dx.doi.org/10.1016/j.lwt.2004.07.012

NASCIMENTO, G. G. F. et al. Antibacterial activity of plant extracts and phytochemicals on antibiotic-resistant bacteria. Brazillian Journal of Microbiology, v. 21, p. 247-256, 2000.

NASCIMENTO, M. R.; STAMFORD, T. L. M. Incidência de Escherichia coli O157:H7. Revista de Higiene Alimentar, v.14, p. 32-35, 2000.

NATIONAL COMMITTEE FOR CLINICAL LABORATORY STANDARDS - NCCLS. Methods for dilution antimicrobial susceptibility tests for bacteria that grow aerobically. Wayne, 2003. Approved standard M7-A6.

NEDOROSTOVA, L. et al. Antimicrobial properties of selected essential oils in vapour phase against foodborne bacteria. Food Control, v. 20, p. 157-160, 2009. http://dx.doi.org/10.1016/j.foodcont.2008.03.007

NEGRAES, P. Guia A-Z de plantas: condimentos. São Paulo: Bei Comunicação, 2003. 267 p.

OGUNWANDE, I. A. et al. Studies on the essential oils composition, antibacterial and cytotoxicity of Eugenia uniflora L. The International Journal of Aromatherapy, v. 15, p. 147-152, 2005. http://dx.doi. org/10.1016/j.ijat.2005.07.004

ONAWUNMI, G. O.; YISAK, W.; OGUNLANA, E. O. Antibacterial constituents in the essential oil of Cymbopogon citratus (DC) Stapf. Journam of Etnopharmacology, v.12, p. 279-286, 1984. http://dx.doi. org/10.1016/0378-8741(84)90057-6

OLIVEIRA, M. M. M. et al. Disinfectant action of Cymbopogon sp. essential oils in different phases of biofilm formation by Listeria monocytogenes on stainless steel surface. Food Control, v. 21, p. 549-553, 2010. http://dx.doi.org/10.1016/j.foodcont.2009.08.003

PEREIRA, A. A. et al. Caracterização química e efeito inibitório de óleos essenciais sobre o crescimento de Staphylococcus aureus e Escherichia coli. Ciência e Agrotecnologia, v. 32, p. 887-893, 2008. http://dx.doi. org/10.1590/S1413-70542008000300028

ROTA, C. M. et al. Antimicrobial activity and chemical composition of Thymus vulgaris, Thymus zygis and Thymus hyemalis essential oils. Food Control, v.19, 681-687, 2008. http://dx.doi.org/10.1016/j. foodcont.2007.07.007

SACCHETTI, G. et al. Comparative evaluation of 11 essential oils of diferent origin as functional antioxidants, antiradicals and antimicrobials in foods. Food Chemistry, v. 91, p. 621-632, 2005. http://dx.doi.org/10.1016/j.foodchem.2004.06.031

SIKKEMA, J.; BONT, J. A. M.; POOLMAN, B. Interactions of cyclic hydrocarbons with biological membranes. Journal of Biological Chemistry, Baltimore, v. 269, p. 8022-8028, 1994.

SIMÕES, C. M. O.; SPITZER, V. Óleos voláteis. In: SIMÕES, C. M. O.; SCHENKEL, E. P.; GOSMANN, G.; MELLO, J. C. P.; MENTZ, L. A.; PETROVICK, P. R. Farmacognosia: da planta ao medicamento. 5. ed. Porto Alegre: UFRGS, p. 467-495, 2004.

SMITH-PALMER, A.; STEWART, J.; FYFE, L. Antimicrobial properties of plant essential oils and essences against five important food-borne pathogens. Letters in Applied Microbiology, v. 26, p. 118, 1998. PMid:9569693. http://dx.doi.org/10.1046/j.1472-765X.1998.00303.x

SMITH-PALMER, A; STEWART, J.; FYFE, L. The potential application of plant essential oils as natural food preservatives in soft cheese. Food Microbiology, v. 18, p. 463-470, 2001. http://dx.doi.org/10.1006/ fmic.2001.0415

SOUZA, E. L. et al. Influence of Origanum vulgare L. essential oil on enterotoxin production, membrane permeability and surface characteristics of Staphylococcus aureus. International Journal of Food Microbiology, v. 137, p. 308-311, 2010.

TAVECHIO, A. T. et al. Salmonella serotypes isolated from nonhuman source in São Paulo, Brazil, from 1996 through 2000. Journal of Food Protection, v. 65, n. 6, p. 1041-1044, 2002. PMid:12092719.

TESKE, M.; TRENTINI, A. M. M. Herbarium compêndio de fitoterapia. 3. ed. Curitiba, 1997. 317 p. 